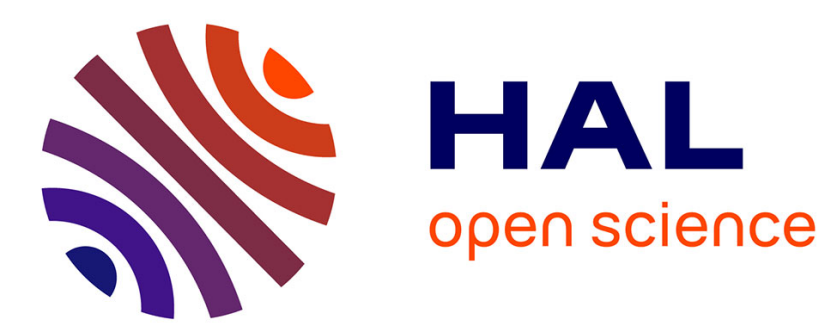

\title{
Bioremediation of Marine Oil Spills
}

\author{
R. C. Prince, R. R. Lessard, J. R. Clark
}

\section{To cite this version:}

R. C. Prince, R. R. Lessard, J. R. Clark. Bioremediation of Marine Oil Spills. Oil \& Gas Science and Technology - Revue d'IFP Energies nouvelles, 2003, 58 (4), pp.463-468. 10.2516/ogst:2003029 . hal-02043885

\section{HAL Id: hal-02043885 \\ https://hal.science/hal-02043885}

Submitted on 21 Feb 2019

HAL is a multi-disciplinary open access archive for the deposit and dissemination of scientific research documents, whether they are published or not. The documents may come from teaching and research institutions in France or abroad, or from public or private research centers.
L'archive ouverte pluridisciplinaire HAL, est destinée au dépôt et à la diffusion de documents scientifiques de niveau recherche, publiés ou non, émanant des établissements d'enseignement et de recherche français ou étrangers, des laboratoires publics ou privés. 


\title{
Bioremediation of Marine 0 il Spills
}

\author{
R.C. Prince ${ }^{1}$, R.R. Lessard ${ }^{2}$ and J.R. Clark ${ }^{2}$ \\ 1 ExxonM obil Research and Engineering Co., Annandale, NJ 08801 \\ 2 ExxonM obil Research and Engineering Co., Fairfax, VA 22037 \\ e-mail: roger.c.prince@exxonmobil.com - richard.r.lessard@exxonmobil.com -jim.r.clark@exxonmobil.com
}

\begin{abstract}
Résumé - Bioremédiation des pollutions maritimes pétrolières - À long terme, la biodégradation constitue l'ultime étape du devenir du pétrole déversé en mer qui ne peut être ramassé ou brûlé. La stimulation de cette biodégradation est donc une option importante pour optimiser l'élimination du pétrole de l'environnement et minimiser l'impact environnemental d'un déversement. Pour le traitement de l'huile flottant à la surface de la mer, les produits dispersants sont intéressants car ils augmentent au maximum l'aire interfaciale disponible pour les attaques microbiennes et favorisent ainsi la biodégradation. Si le pétrole se répand sur les côtes, il est probable que la biodégradation soit limitée par des nutriments tels que l'azote et le phosphore, d'autre part, l'application raisonnée d'engrais stimule la biodégradation du pétrole résiduel en place. Ces approches constituent un parfait exemple de technologies environnementales modernes : fonctionner en s'appuyant sur les phénomènes naturels afin d'obtenir un nettoyage rapide tout en minimisant les effets indésirables sur l'environnement.
\end{abstract}

Abstract - Bioremediation of Marine Oil Spills - In the long run, biodegradation is the eventual fate of oil spilled at sea that cannot be collected or burnt. Stimulating this biodegradation is thus an important option for maximizing the removal of oil from the environment, and minimizing the environmental impact of a spill. For handling oil while it is still floating on the sea surface, dispersants are advantageous because they maximize the surface area available for microbial attack, and stimulate biodegradation. If oil beaches on a shoreline, it is likely that biodegradation is limited by nutrients such as nitrogen and phosphorus, and the careful application of fertilizers stimulates the biodegradation of residual beached oil. These approaches epitomize modern environmental technologies; working with natural phenomena to achieve a more rapid clean-up while minimizing undesirable environmental impacts. 


\section{IN TRO DUCTIO N}

It is no exaggeration that oil fuels the world's economy, and it is used on a staggering scale. World production was some $80 \mathrm{Mbbl}$ (11 Mt/day) by the end of 2000, and this is expected to increase by $1.9 \% / y e a r$ in the next decade [1]. Approximately $40 \%$ of the world's oil travels by water at some time between its production and final consumption, and again the volumes are staggering. For example, the US imported $350000 \mathrm{t}$ of oil per day from the Middle East alone in 1999 [1]. Unfortunately, despite the best efforts of the major part of the petroleum industry, a small amount is inevitably spilled. Fortunately this is only a tiny fraction of that transported, and there has been a general improvement in oil spill statistics in the last two decades [1,2].

Massive releases from pipelines, wells and tankers receive the most public attention, but in fact these account for only a relatively small proportion of the total petroleum entering the environment. The National Research Council has recently updated its classic Oil in the Sea [1] and now estimates that the total input of petroleum into the sea from all sources is approximately $1.3 \mathrm{Mt} / \mathrm{year}$. Almost 50\% comes from natural seeps, and less than $9 \%$ emanates from catastrophic releases. Consumption, principally due to non-tanker operational discharges and urban run-off, is responsible for almost $40 \%$ of the input (Fig. 1).

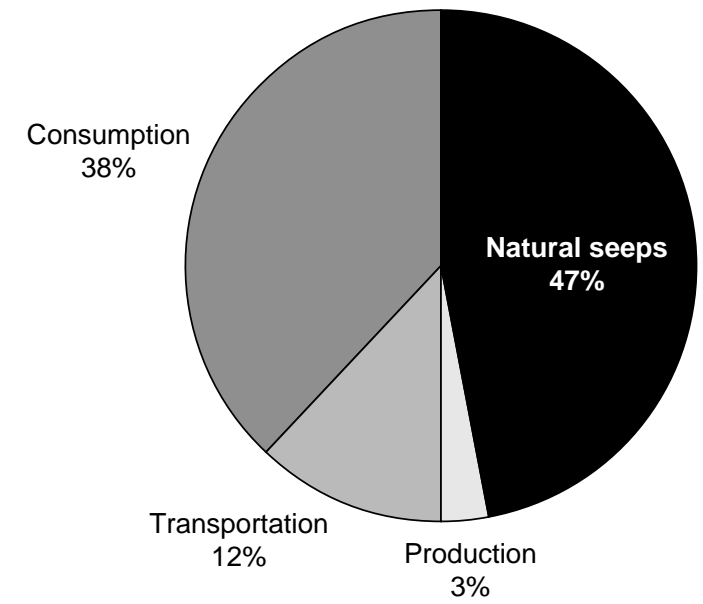

Figure 1

Sources of oil into the sea.

Nevertheless, major oil spills highlight the need for environmentally responsible and cost-effective mitigation technologies. Marine spills generate widespread public concern, with enormous pressure on the responsible parties, backed by legislation, for prompt response and resolution of the problem. Physical collection of the oil with booms, skimmers and adsorbents is generally the first priority of responders, but this is rarely easy, nor very effective after a large spill. There is therefore a continuing search for alternative and additional responses. Amongst the most promising are those that aim to stimulate the natural process of oil biodegradation.

\section{BIODEGRADATION OF CRUDE OIL}

Hydrocarbons have been part of the marine environment for millennia; the average age of crude oil in commercial production is some $100 \mathrm{Ma}$, and seeps have probably always been significant contributors to the biosphere, as they are today (Fig. 1). The composition of crude oils varies substantially, but Tissot and Welte [3] quote the average composition of 527 crude oil samples as $58.2 \%$ saturated, $28.6 \%$ aromatic and $14.2 \%$ polar compounds. The absolute values vary widely in different oils, but on average there is rough parity between paraffins, naphthenes and aromatics. Paraffins are saturated linear and branched hydrocarbons, and naphthenes are cyclic saturated hydrocarbons; by convention, molecules that have saturated ring structures attached to aromatic rings are included in the aromatic fraction. Modern biogenic hydrocarbons are also important carbon sources in the sea; many are produced by planktonic algae, while others are volatilized by terrestrial plants and are washed into the sea [1]. It is thus no surprise that oil-degrading microorganisms are ubiquitous in the world's oceans [4]. Research in the last 30 years has elucidated much of the microbial, genetic and biochemical diversity of these organisms. More than 170 genera of microorganisms have been identified that are able to degrade hydrocarbons, and we now have a clear understanding of some of the pathways involved in the aerobic biodegradation of aliphatic and aromatic compounds [4]. Hydrocarbons are not all biodegraded at similar rates, and not all hydrocarbons are degradable, but estimates for the biodegradability of different crude oils range from 70 to $97 \%$ [4-7]. What remain are principally the asphaltenes and resin compounds; these lack oiliness, are friable in small quantities, and are essentially biologically inert.

So how can bioremediation, the stimulation of the natural process of biodegradation, be integrated into oil spill response? It is useful to consider what happens when oil is released into the marine environment. Almost all oils in commerce float, so any spilled material will spread on the water. There are exceptions such as the very heavy fuel oil that spilled from the Presidente Rivera into the Delaware River in June 1989 [8], but these are uncommon. The spreading increases the surface area of the slick, and encourages the evaporation of smaller molecules [9]. Most crude oils contain an enormous array of hydrocarbons, ranging in size from methane to molecules with hundreds of 
carbons. Usually molecules with up to about 12 carbons evaporate [9], and while they are thus removed from the spill site, they are subsequently destroyed either by atmospheric photochemistry, or by biodegradation after they are washed from the atmosphere by rain. At the same time, a small amount of the hydrocarbons will dissolve into the underlying water [10], while photochemistry may oxidize some of the larger aromatic compounds in the slick [11]. The floating slick will also absorb water [12]. In time the oil will disperse naturally in the water, aided by wave energy. If the oil spill occurs in severe weather, the oil may be dispersed into the water column in a matter of hours, as happened to the $8.3 \times 10^{7} 1$ of light crude oil from the Braer off the Shetland Islands in January 1993 [13]. Dispersed oil has a very large surface area, and biodegradation is likely to be rapid.

If the spill is near land, it is likely that some oil will become stranded on the shoreline. Again, physical collection is the response of choice. Scraping the oil into trenches and recovering it with vacuum trucks is the usual response on sandy shores: for example this was used very effectively following the Sea Empress spill in Wales in February 1996 [14]. On rocky shores the usual response is to wash the oil back into the sea, and collect it with skimmers, as was done following the 1989 Exxon Valdez spill in Alaska [15]. Any residual oil will either leave the shoreline flocculated with small neutrally buoyant particles of silt [16], and be biodegraded [17], or eventually be biodegraded on the beach [3-7]. As we shall see below, the stimulation of this process by adding fertilizers has been shown to be safe and effective.

\section{DISPERSANTS}

One major option for stimulating biodegradation of spilled oil is to encourage natural dispersion by adding chemical dispersants to the oil slick [18-20]. ExxonMobil has a long history of developing safe and effective dispersants, for example the development of "self-mixing" dispersants that are effective even when there is relatively little wave energy to aid the dispersion [21]. ExxonMobil's Corexit $9527^{\circledR}$ was developed in 1972, and became one of the world's most widely used dispersants.

While Corexit $9527^{\circledR}$ is very effective on fresh oil, it is less effective on oil that has lost lighter compounds by evaporation and become more viscous, or has absorbed large amounts of water. Thus as oil viscosity rises above 7000-10 000 centipoise (cp) as a result of weathering, Corexit $9527^{\circledR}$ and most other dispersants lose their effectiveness. This means that these dispersants must be applied promptly to ensure their efficacy. To deal with heavier and weathered oils, Exxon therefore developed Corexit $9500^{\circledR}$ in 1992. This dispersant effectively extends the "window of opportunity" because it is effective on crudes with viscosities up to $20000 \mathrm{cp}$. Corexit $9500^{\circledR}$ contains the same surfactants at essentially the same high concentration as Corexit $9527^{\circledR}$, but with improved solvents. For the majority of crude oils as well as bunkers (heavy fuel oils), Corexit $9500^{\circledR}$ can be applied much later in the spill than less robust products and still be effective $[22,23]$. For most species it is also lower in toxicity than other dispersants, though the toxicity of dispersants is becoming increasingly less of an issue than effectiveness because of the very rapid dilution to extremely low levels in the water column [24-26].

Another important feature of Corexit $9500^{\circledR}$ is its capability to break emulsions and disperse the oil, as has been demonstrated in large-scale field tests in the North Sea [27]. This is a major advance in oil dispersant technology because it was thought that dispersants were no longer effective once water-in-oil emulsions form at the sea surface.

The use of dispersants has always been thought to stimulate the natural process of biodegradation, because microbial attack is at the oil-water interface and the dispersion of the oil dramatically increases the area available for microbial colonization $[1,18]$. Since the oil is dispersed into such a large volume, other nutrients required for the growth of bacteria, such as nitrogen, are not limiting because they are available in sufficient concentrations. The rate of biodegradation of oil droplets is immediately enhanced by the dispersion process, and much of the oil can be converted to microbial biomass, $\mathrm{CO}_{2}$ and water over the following days to weeks [28-31].

There may also be additional benefits from the surfactants themselves, for it has recently been shown that the surfactants used in Corexit $9527^{\circledR}$ and $9500^{\circledR}$ enhance the biodegradation of dispersed oil by providing a digestible substrate that stimulates the growth of organisms and makes more of them available to attack the oil [28, 29]. Dispersants containing these surfactants are thus one way of stimulating the rate of biodegradative removal of oil from the marine environment. Recent work also shows that they can be safely used near-shore to minimize the oiling of shorelines [32, 33], although recent regulations may limit their use in some parts of the world. The United Kingdom has a protocol for approving dispersants that can be used on shorelines. In fact, all products must pass this protocol, even to be used out at sea. This has limited use of Corexit products in the United Kingdom as they have been unable to pass the rocky shore test, as it is called. Work is underway to modify the formula to overcome this restriction. In the United States approval of products for shoreline use is totally distinct and separate from at-sea approval and Corexit dispersants are fully approved for at-sea use, accounting for the overwhelming percentage of stockpiled products. United States regulations have recently been proposed that will require dispersant use in those areas where they are pre-approved any time spilled oil is in the preapproved zones. 


\section{SHORELINE BIOREMEDIATION}

Biodegradation is the ultimate fate of any oil not collected (or burned [34]) during a spill response, so stimulating this process is an appealing option. As discussed above, oildegrading microorganisms are ubiquitous, but their abundance is usually limited by low levels of hydrocarbons in the environment. An oil spill obviates this limitation, and there is typically a population explosion of oil degrading microorganisms after a spill [35-37]. Where once their growth was limited by the availability of hydrocarbon, it is now limited by something else. In aerobic environments, the most likely limiting nutrients are nitrogen and phosphorus, followed by iron and other trace nutrients. In marine systems, these nutrients are virtually unlimited, although they are low levels, and they are delivered by every tide. It is thus no surprise that oil degradation proceeds without human intervention.

The simplest way of stimulating biodegradation, and the only one that has achieved experimental verification in the field, is to carefully add nitrogen and phosphorus nutrients. This was first used on a large scale in Alaska, following the 1989 spill from the Exxon Valdez [38-40]. Two fertilizers were used in the large-scale applications: an oleophilic liquid product designed to adhere to oil (Inipol EAP22 [41]), and a slow-release granular agricultural product (Customblen). Inipol EAP22 is a microemulsion containing an internal phase of urea in aqueous solution in an external oil phase of oleic acid and trilaureth-4-phosphate, cosolubilized by butoxy-ethanol. It contains $7.4 \%$ nitrogen and $0.7 \%$ phosphorus by weight. Inipol EAP22 was applied with airless sprayers transported on small pontoon catamarans. Customblen is a high quality agricultural fertilizer designed to release its nutrients over several weeks. It consists primarily of ammonium nitrate, calcium phosphate and ammonium phosphate, encapsulated in a polymerized linseed oil covering. Customblen contains 28\% nitrogen and 3.5\% phosphorus by weight. It was applied with broadcast spreaders carried by workers walking the beaches.

The rationale behind the use of these two products was that the Inipol EAP22 would adhere to the oil film on surface beach material, stimulating its degradation, while the Customblen would become lodged in the shoreline gravel and slowly release nutrients that would penetrate subsurface sediments. Thus Inipol EAP22 was applied where there was surface oil, and Customblen where there was subsurface oil. Both fertilizers were applied when both surface and subsurface oil was present. In 1989, Customblen was applied at $28.7 \mathrm{~g} / \mathrm{m}^{2}$, and Inipol EAP22 at $0.31 \mathrm{1} / \mathrm{m}^{2}$, based on USEPA calculations of the highest concentrations of ammonia that could be released, with the lowest dilution, and still maintain acceptable water quality. In 1990, the dose of Customblen was amended to $15.8 \mathrm{~g} / \mathrm{m}^{2}$ if applied with Inipol EAP22, and $95.7 \mathrm{~g} / \mathrm{m}^{2}$ if applied alone. Inipol EAP22 could be reapplied after 30 days, and Customblen after 15 days, if required. In 1991 the guidelines for Customblen application were further increased to up to $95.7 \mathrm{~g} / \mathrm{m}^{2}$ if applied with Inipol EAP22, and up to $191.3 \mathrm{~g} / \mathrm{m}^{2}$ when applied alone. Inipol EAP22 was thus the principal fertilizer used in the first year of the cleanup, while Customblen was used more widely in subsequent years after the surface sediments were clean. More than $120 \mathrm{~km}$ of shoreline were treated in 1989, using a total of approximately $23 \mathrm{t}$ of nitrogen. A similar amount was used as several treatments of a much smaller length of shoreline in 1990, and because the clean up had been so successful, only approximately $3 \mathrm{t}$ of nitrogen were applied in 1991, the third and final year of the clean up [39].

The bioremediation was very successful, as shown in a joint monitoring program conducted by Exxon, the USEPA and the Alaska Department of Environmental Conservation [40]. The fertilizer applications were successful at delivering nutrients throughout the oiled part of the shorelines, microbial activity was enhanced, and oil biodegradation was stimulated 2 to 5 fold [38-40]. Furthermore, this was achieved with no detectable adverse environmental impact [38-40].

Since then, bioremediation has been used on a limited site as part up of the cleanup of the Sea Empress spill [42], and has been demonstrated on experimental spills in marine or brackish environments on the Delaware Bay [43], a Texas wetland [44], a fine-sand beach in England [45], mangroves in Australia [46], and an Arctic shoreline in Spitsbergen [47]. It is likely to be included in responses to future spills where oil strands on rocky or inaccessible shorelines. It is important to note that success to date has relied on stimulating the growth of the indigenous bacteria. Several companies offer microbial inocula for bioremediation purposes, but there has been no clear demonstration that these products offer any advantage over the indigenous organisms [e.g. 48].

When bioremediation is to be used as part of the response to an oil spill, the results of the Alaska experience [38-40] and the various field tests [42-47] can be summarized to recommend a tiered monitoring approach on a representative piece of shoreline to ensure success:

- Monitor fertilizer nutrients in interstitial water from the oiled zone of the beach, and adjust application rates and frequencies to keep nitrogen nutrients near $100 \mu \mathrm{M}$. Simple field test kits are adequate for this [47].

- Monitor dissolved oxygen levels in the interstitial water; a decrease probably indicates increased microbial activity caused by the fertilizer. Simple field test kits are adequate for this [40, 47].

- Monitor carbon dioxide evolution from a beach; increased evolution suggests the bioremediation strategy is working. Portable infrared spectrometers are adequate for this $[49,47]$. 
- After some months, take samples for analysis of the spilled oil by GC/MS, and use conserved internal markers in the oil to evaluate biodegradation [50]. Calculate the percent depletion of analytes within the oil using the equation:

$$
\% \text { loss }=\left[\left(\left(A_{0} / C_{0}\right)-\left(A_{s} / C_{s}\right)\right) /\left(A_{0} / C_{0}\right)\right] \times 100
$$

Where: $A_{s}$ and $C_{s}$ are the concentrations of the target analyte(s) and conserved marker in the oil sample, respectively, and $A_{0}$ and $C_{0}$ are the concentrations in the initially spilled oil.

Bioremediation epitomizes modern environmental technologies; working with natural phenomena to achieve a more rapid cleanup while minimizing undesirable environmental impacts. The careful application of dispersants on floating oil, and fertilizers to oiled shorelines, can speed removal of oil from the environment with minimal additional environmental impact.

\section{REFEREN CES}

1 National Research Council, (2002) Oil in the Sea III: Inputs, Fates and Effects, National Academy of Sciences, Washington DC.

2 McMahon Anderson, C. and Labelle, R.P (2000) Update of comparative occurrence rates for offshore oil spills. Spill Science Technology Bulletin, 6, 303-321.

3 Tissot, B.P. and Welte, D.H. (1984) Petroleum Formation and Occurrence, Springer-Verlag, Berlin.

4 Prince, R.C. (2002) Petroleum and other hydrocarbons, biodegradation of. In: Encyclopedia of Environmental Microbiology (G. Bitton, G., ed.) John Wiley, New York, 2402-2416.

5 Prince, R.C., Varadaraj, R., Fiocco, R.J. and Lessard, R.R. (1999) Bioremediation as an oil spill response tool. Environmental Technology, 20, 891-896..

6 Prince, R.C. (1993) Petroleum spill bioremediation in marine environments. Critical Reviews in Microbiology, 19, 217 242.

7 Prince, R.C. (1997) Biodegradation of crude oil. In: Encyclopedia of Environmental Analysis and Remediation. John Wiley, New York, 2, 1327-1342.

8 Wiltshire, G.A. and Corcoran, L. (1991) Response to the Presidente Rivera major oil spill, Delaware River. In: Proceedings of the 1991 International Oil Spill Conference, American Petroleum Institute, Washington DC, 253-258.

9 Fingas, M.F. (1995) A literature review of the physics and predictive modeling of oil spill evaporation. Journal of Hazardous Materials, 42, 157-175.

10 Yaws, C.L., Pan, X. and Lin, X. (1993) Water solubility data for 151 hydrocarbons. Chemical Engineering, 100, 2, 108111.

11 Garrett, R.M., Pickering, I.J., Haith, C.E. and Prince, R.C. (1998) Photooxidation of crude oils. Environmental Science and Technology, 32, 3719-3723.

12 Bobra, M. (1991) Water in oil emulsification: a physicochemical study. In: Proceedings of the 1991 International Oil Spill Conference, American Petroleum Institute, Washington DC, 483-492.
13 Thomas, R. and Lunel, T. (1993) The Braer incident; dispersion in action. In: Proceedings of the Sixteenth Arctic Marine Oilspill Program Technical Seminar, Edmonton, Alberta, 843-859.

14 Lunel, T., Lee, K., Swannell, R., Wood, P., Rusin, J., Bailey, N., Halliwell, C., Davies, L., Sommerville, M., Dobie, A., Mitchell, D. and McDonagh, M. (1996) Shoreline clean up during the Sea Empress incident: the role of surf washing (clay oil flocculation), dispersants and bioremediation. In Proceedings of the Nineteenth Arctic and Marine Oil Spill Program Seminar. Environment Canada, 1521-1540.

15 Nauman, S.A. (1991) Shoreline clean-up: equipment and operations. In: Proceedings of the 1991 International Oil Spill Conference, American Petroleum Institute, Washington DC, 141-148.

16 Owens, E.H., (1999) The interaction of fine particles with stranded oil. Pure and Applied Chemistry, 71, 83-93.

17 Weise, A. and Lee, K. (1997) The effect of clay-oil flocculation on natural oil biodegradation. In: Proceedings of the 1997 International Oil Spill Conference, American Petroleum Institute, Washington, D.C. , 955-956.

18 National Research Council (1989) Using Oil Spill Dispersants on the Sea, National Academy of Science, Washington, DC.

19 Fiocco, R.J. and Lewis, A. (1999) Oil spill dispersants. Pure and Applied Chemistry, 71, 27-42.

20 Lessard, R.R. and DeMarco, G. (2000) The significance of oil spill dispersants. Spill Science \& Technology Bulletin, 6, 59-68.

21 Canevari, G.P. (1973) Development of the "Next Generation" Chemical Dispersants. In: Conference on Prevention and Control of Oil Spills; American Petroleum Institute, Washington, D., 231-240.

22 Fiocco, R.J. and Lessard, R.R. (1997) Demulsifying dispersant for an extended window of use. In: Proceedings of the 1997 International Oil Spill Conference, American Petroleum Institute, Washington, D.C., 1015-1016.

23 Strom-Kristiansen, T., Lewis, A., Daling, P.S., Hokstad, J.N. and Singsaas, I. (1997) Weathering and dispersion of naphthenic, asphaltenic and waxy crude oils. In: Proceedings of the 1997 International Oil Spill Conference, American Petroleum Institute, Washington, DC, 631-636.

24 Lewis, A. and Aurand, D. (1997) Putting dispersants to work: overcoming obstacles. 1997 International Oil Spill Conference Issue Paper, American Petroleum Institute, Washington, DC, Technical Report \#IOSC-004.23.

25 GeorgeAres, A. and Clark, J.R. (2000) Aquatic toxicity of two Corexit® dispersants. Chemosphere, 40, 897-906.

26 Clark, J.R., Bragin, G.E., Febbo, E.J. and Letinski, D.J. (2001) Toxicity of physically and chemically dispersed oils under continuous and environmentally realistic exposure conditions: Applicability to dispersant use decisions in spill response planning. Proceedings of the 2001 International Oil Spill Conference, American Petroleum Institute, Washington, DC, 1249-1255.

27 Lewis, A., Daling, P.S., Strom-Kristiansen, T., Nordvik, A.B. and Fiocco, R.J. (1995) Weathering and chemical dispersion of oil at sea. In: Proceedings of the 1995 International Oil Spill Conference, American Petroleum Institute, Washington, D.C., 157-164.

28 Varadaraj, R., Robbins, M.L., Bock, J., Pace, S. and MacDonald, D. (1995) Dispersion and biodegradation of oil spills on water. In: Proceedings of the 1995 International Oil Spill Conference, American Petroleum Institute, Washington DC, 101-106. 
29 Swannell, R.P.J. and Daniel, F. (1999) Effect of dispersants on oil biodegradation under simulated marine conditions. Proceedings of the 1999 International Oil Spill Conference American Petroleum Institute, Washington, DC, 169-176.

30 Crescenzi, R., Camilli, M., Fascetti, E., Porcelli, F., Prosperi, G. and Sacceddu, P. (1999) Microbial degradation of biosurfactant dispersed oil. Proceedings of the 1999 International Oil Spill Conference, American Petroleum Institute; Washington, DC, 1039-1042.

31 Harris, B.C., Bonner, J.S., McDonald, T.J., Fuller, C.B., Page, C.A., Dimitriou-Christidis, P., Sterling, M.C., and Autenrieth, R.L. (2002) Bioavailability of chemicallydispersed oil. Proceedings of the Twenty-fifth Arctic and Marine Oil Spill Conference, Environment Canada, Ottawa, 895-905.

32 Page, C.A., Bonner, J.S., Sumner, P.L., McDonald, T.J., Autenrieth, R.L., and Fuller, C.B. (2000) Behavior of a chemically-dispersed oil and a whole oil on a near-shore environment. Water Research, 34, 2507-2516.

33 Page, C.A., Bonner, J.S., McDonald, T.J. and Autenrieth, R.L. (2002) Behavior of a chemically dispersed oil in a wetland environment. Water Research 36, 3821-3833.

34 Buist, I., McCourt, J., Potter, S., Ross, S. and Trudel, K. (1999) In situ burning. Pure and Applied Chemistry, 71, 4366.

35 Macnaughton, S.J., Stephen, J.R., Venosa, A.D., Davis, G.A., Chang, Y.J. and White, D.C. (1999) Microbial population changes during bioremediation of an experimental oil spill. Applied and Environmental Microbiology, 65, 3566-3574.

36 Grossman, M.J., Prince, R.C., Garret, R.M., Garret, K.K., Bare, R.E., O’Neil, K.R., Sowlay, M.R., Hinton, S.M., Lee, K., Sergy, G.A. Owens, E.H. and Guénette, C.C. (2000) Microbial diversity in oiled and unoiled shoreline sediments in the Norewegian Arctic. In: Proceedings of the 8th International Symposium on Microbial Ecology, (Bell, C.R., Brylinski, M. and Johnson-Green, P., eds.) Atlantic Canada Society for Microbial Ecology, Halifax, NS, 775-789.

37 Kasai, Y., Kishira, H., Sasaki, T., Syutsubo, K., Watanabe, K. and Harayama, S. (2002) Predominant growth of Alcanivorax strains in oil-contaminated and nutrientsupplemented sea water. Environmental Microbiology, 4, 141-147.

38 Bragg, J.R., Prince, R.C., Harner, E.J. and Atlas, R.M. (1994) Effectiveness of bioremediation for the Exxon Valdez oil spill. Nature, 368, 413-418.

39 Prince, R.C. and Bragg, J.R. (1997) Shoreline bioremediation following the Exxon Valdez oil spill in Alaska. Bioremediation Journal, 1, 97-104.

40 Prince, R.C., Clark, J.R., Lindstrom, J.E., Butler, E.L., Brown, E.J., Winter, G., Grossman, M.J., Parrish, R.R., Bare, R.E., Braddock, J.F., Steinhauer, W.G., Douglas, G.S., Kennedy, J.M., Barter, P.J., Bragg, J.R., Harner, E.J. and Atlas, R.M. (1994) Bioremediation of the Exxon Valdez oil spill: monitoring safety and efficacy. In Hydrocarbon Remediation (R.E. Hinchee, B.C. Alleman, R.E. Hoeppel and R.N. Miller, eds.), Lewis Publishers, Boca Raton, FL., 107-124.

41 Ladousse, A. and Tramier, B. (1991) Results of 12 years of research in spilled oil bioremediation: Inipol EAP22. In: Proceedings of the 1991 International Oil Spill Conference, American Petroleum Institute, Washington DC, 577-582.

42 Swannell, R.P.J., Mitchell, D., Lethbridge, G., Jones, D., Heath, D., Hagley, M., Jones, M., Petch, S., Milne, R., Croxford, R. and Lee, K. (1999) A field demonstration of the efficacy of bioremediation to treat oiled shorelines following the Sea Empress incident. Environmental Technology, 20, 863-873.

43 Venosa, A.D., Suidan, M.T., Wrenn, B.A., Strohmeier, K.L., Haines, J.R., Eberhart, B.L., King, D. and Holder, E (1996) Bioremediation of an experimental oil spill on the shoreline of Delaware Bay. Environmental Science and Technology, 30, 1764-1775.

44 Mills, M.A., Bonner, J.S., Simon, M.A., McDonald, T.J. and Autenrieth, R.L. (1997) Bioremediation of a controlled oil release in a wetland. In: Proceedings of the Twentieth Arctic and Marine Oilspill Program (AMOP) Technical Seminar, 1, 609-616.

45 Swannell, R.P.J., Mitchell, D., Jones, D.M., Petch, S., Head, I.M., Wilis, A., Lee, K. and Lepo, J.E. (1999) Bioremediation of oil-contaminated fine sediment. In: Proceedings of the 1999 International Oil Spill Conference. American Petroleum Institute, Washington DC, 751-756.

46 Ramsay, M.A., Swannell, R.P.J., Shipton, W.A., Duke, N.C., and Hill, R.T. (2000) Effect of bioremediation on the microbial community in oiled mangrove sediments. Marine Pollution Bulletin, 41, 413-419.

47 Prince, R.C., Bare, R E., Garrett, R.M., Grossman, M.J., Haith, C.E., Keim, L.G., Lee, K., Holtom, G.J., Lambert, P., Sergy, G.A., Owens, E.H. and Guénette, C.C. (1999) Bioremediation of a marine oil spill in the Arctic, In: In Situ Bioremediation of Petroleum Hydrocarbon and Other Organic Compounds. (Alleman, B.C. and A. Leeson, eds.), Battle Press, Columbus, OH, 227-232.

48 Venosa, A.D., Haines, J.R. and Allen, D.M. (1992) Efficacy of commercial inocula in enhancing biodegradation of weathered crude oil contaminating a Prince William Sound beach. Journal of Industrial Microbiology, 10, 1-11.

49 Swannell, R.P.J., Lee, K., Basseres, A. and Merlin, F.X. (1994). A direct respirometric method for in situ determination of bioremediation efficiency. In: Proceedings of the Seventeenth Arctic Marine Oilspill Program Technical Seminar, Environment Canada, Ottawa, ON, 1273-1286.

50 Prince, R.C., Elmendorf, D.L., Lute, J.R., Hsu, C.S., Haith, C.E., Senius, J.D., Dechert, G.J., Douglas, G.S. and Butler, E.L. (1994) $17 \mathrm{a}(\mathrm{H}), 21 \mathrm{~b}(\mathrm{H})$-hopane as a conserved internal marker for estimating the biodegradation of crude oil. Environmental Science and Technology, 28, 142-145.

Final manuscript received in February 2003 